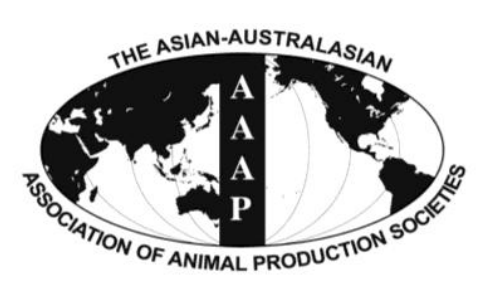

\title{
Rice Distillers Dried Grain Is a Promising Ingredient as a Partial Replacement of Plant Origin Sources in the Diet for Juvenile Red Seabream (Pagrus major)
}

\author{
Jin Choi, Md Mostafizur Rahman, and Sang-Min Lee* \\ Department of Marine Bioscience and Technology, Gangneung-Wonju National University, \\ Gangneung 210-702, Korea
}

\begin{abstract}
This study was designed to test the effects of dietary distillers dried grain (DDG) level on the growth performance, feed utilization, body composition and antioxidant activity of juvenile red seabream (Pagrus major). Six isonitrogenous and isocaloric diets were formulated to contain $0 \%, 5 \%, 10 \%, 15 \%, 20 \%$, and 25\% DDG from rice (designated as DDG0, DDG5, DDG10, DDG15, DDG20, and DDG25), respectively. Juvenile red seabream averaging 10.1 $\pm 0.05 \mathrm{~g}$ were randomly distributed into $400-\mathrm{L}$ tanks in a flow through systems. Three replicate groups of fish were fed one of the experimental diets to visual satiation two times a day for 10 weeks. Survival, weight gain, feed efficiency, protein efficiency ratio and hepatosomatic index of fish were not affected by dietary DDG levels ( $>0.05)$. Proximate and amino acid composition of whole body in juvenile red seabream were not affected by dietary DDG levels ( $>0.05)$. Plasma content of total protein, glucose, cholesterol, glutamic-pyruvic transaminase, phospholipid and triglyceride were not affected by dietary DDG levels ( $>>0.05$ ). 1, 1-Diphenyl-2-picryl-hydrazyl radical and alkyl radical scavenging activities in plasma and liver of fish were not affected by dietary DDG levels $(p>0.05$ ). The results of this experiment suggest that DDG has the potential to replace plant origin ingredients such as wheat flour and corn gluten meal and could be used up to $25 \%$ in diet without incurring negative effects on the growth performance of juvenile red seabream. (Key Words: Pagrus major, Distillers Dried Grain, Growth, Antioxidant Activity)
\end{abstract}

\section{INTRODUCTION}

In aquaculture diets, feed is generally the single largest expenditure for most aquatic species and it accounts for up to $60 \%$ of the total farm production cost (Cheng and Hardy, 2004). Due to the shortage and expense of many imported ingredients such as wheat flour (Rahman et al., 2013), there is additional merit in identifying a new alternative ingredient for target fish. Replacement of wheat flour with less expensive ingredients would be useful in minimizing feed cost. The success of reducing the expense of the prepared diet, without lowering fish performance, leads to a positive effect on the profitability of commercial fish

\footnotetext{
* Corresponding Author: Sang-Min Lee. Tel: +82-33-640-2414, Fax: +82-33-640-2955, E-mail: smlee@gwnu.ac.kr

Submitted Mar. 19, 2014; Revised May 31, 2014; Accepted Jul. 8, 2014
}

production.

Distillers dried grain (DDG) is a cereal by-product which is fermented and distilled to obtain alcoholic beverage (Hertrampf and Piedad-Pascual, 2000). The DDG has been documented as a promising feed ingredient in the poultry and livestock industries (Cheng and Hardy, 2004; Jacob et al., 2008) because it is highly nutritious and economical. Researchers have worked with incorporation of DDG in aquafeed (Chevanan et al., 2007,2010; Kannadhason et al., 2009). The enhanced availability and potential cost-benefit of DDG in aquafeed presents a substantial economic value as it is less expensive than other protein/energy sources like soybean meal (He et al., 2013). However, little information is available on the potential use of DDG from rice for red seabream. Our earlier study recommended that rice-based DDG may well offer an economical ingredient to make lower-cost feed and allow a 
reasonable amount of wheat flour substitution in juvenile olive flounder, Paralichthys olivaceus, diets (Rahman et al., 2013). Research has shown that corn-based DDG is considered an acceptable ingredient in diets for some fish species such as rainbow trout (Cheng and Hardy, 2004), channel catfish (Lim et al., 2009; Li et al., 2010), tilapia (Shelby et al., 2008) and sunshine bass (Thompson et al., 2008).

Red seabream (Pagrus major) is one of the most valuable and widely farmed marine fish species in Asia and its production was established on a commercial scale more than 20 years ago (Foscarini, 1988). To sustain a productive and cost-effective red seabream culture operation, a reliable feed must be produced which is both acceptable and improves growth and survival of the fish under culture. Based on our findings, we conclude that DDG in the diet might be able to maintain fish growth while reducing feed expenditure. Therefore, the present study was conducted to examine the effects of DDG on growth performance, body composition and antioxidant activity of juvenile red seabream.

\section{MATERIALS AND METHODS}

\section{Experimental diets}

Essential amino acid and proximate composition of ingredients used in the experimental diets are presented in Table 1. Ingredients and chemical composition of the experimental diets are presented in Table 2. The six experimental diets were formulated to contain $0 \%, 5 \%, 10 \%$,

Table 1. Composition of proximate and essential amino acids of the ingredients of experimental diets

\begin{tabular}{lccc}
\hline & \multicolumn{3}{c}{ Ingredients } \\
\cline { 2 - 4 } & Fish meal & Wheat flour & $\begin{array}{c}\text { Distillers dried } \\
\text { grain powder }\end{array}$ \\
\hline Proximate composition & \%, dry matter basis) \\
Dry matter & 95.8 & 89.3 & 98.2 \\
Crude protein & 75.3 & 19.3 & 19.1 \\
Crude lipid & 8.8 & 3.9 & 7.8 \\
Ash & 14.6 & 2.2 & 0.5 \\
Essential amino acid composition & $\%$ protein) & \\
Arg & 6.7 & 5.7 & 6.9 \\
His & 2.3 & 2.9 & 2.0 \\
Ile & 4.5 & 2.3 & 3.6 \\
Leu & 8.3 & 6.0 & 8.0 \\
Lys & 8.8 & 3.7 & 3.1 \\
Met+Cys & 5.1 & 2.8 & 3.4 \\
Phe+Tyr & 8.1 & 6.8 & 10.8 \\
Thr & 4.8 & 3.5 & 4.7 \\
Val & 4.5 & 3.2 & 5.8 \\
\hline
\end{tabular}

${ }^{1}$ Residue obtained by filtration of an aqueous mixture of fermented rice with Aspergillus oryzae and yeasts produced from Incheon Makgeolli factory (Incheon, Korea).
$15 \%, 20 \%$, and 25\% DDG from rice (designated as DDG0, DDG5, DDG10, DDG15, DDG20, and DDG25) with isonitrogenous and isocaloric diets. Pollack fish meal was used as the primary protein source. Fish oil was used as lipid source. The DDG used in this study was produced by filtration of an aqueous mixture of fermented rice with Aspergillus oryzae and yeasts in manufactured by Incheon Makgeolli factory (Incheon, Korea). The ingredient was dried at $60^{\circ} \mathrm{C}$ for $24 \mathrm{~h}$ and finely ground prior to incorporating in the experimental diets. All ingredients were carefully combined with $30 \%$ distilled water and pellets were prepared using laboratory moist pelleting equipment. The pellets were dried at room temperature for $48 \mathrm{~h}$ and finely grounded into desirable particle sizes. All diets were stored at $-30^{\circ} \mathrm{C}$ until utilized.

\section{Experimental fish and feeding conditions}

Juvenile red seabream were transported from a private hatchery (Namhae, Korea) to the Marine Biology Center for Research and Education at Gangneung-Wonju National University. The fish were acclimated to laboratory conditions by feeding commercial pellets for 2 weeks before starting the feeding trial. After this conditioning period, juvenile red seabream (mean body weight $10.1 \pm 0.05$ g) were randomly distributed in 18 tanks (400-L rectangular plastic tanks) at a density of 30 fish per tank, respectively. Each experimental diet was fed to three groups of fish to apparent satiation two times per day (9:00 and 17:00 h for 6 days per week) for $10 \mathrm{wks}$. Filtrated seawater was supplied at a flow rate of $4 \mathrm{~L} / \mathrm{min}$ in each tank and the mean water temperature and salinity were $20.4 \pm 1.98^{\circ} \mathrm{C}$ and $34 \pm 0.1 \mathrm{ppt}$, respectively. The photoperiod was left under natural conditions during the feeding trail. Records were kept of daily feed consumption, mortalities, and feeding behavior.

\section{Sample collections and analytical methods}

At the end of the feeding trial, all fish in each tank were collectively weighed immediately after anesthetizing with tricaine methanesulfonate (MS222, Sigma, St. Louis, MO, USA) at a concentration of $100 \mathrm{ppm}$, and after starvation for $24 \mathrm{~h}$. Proximate composition was analyzed according to standard methods (AOAC, 1995). Ten fish per tank at the end of the feeding trials were sampled and stored at $-25^{\circ} \mathrm{C}$ for proximate composition analysis. Crude protein was determined by the Kjeldahl method using an auto Kjeldahl System (Buchi, Flawil, Switzerland). Crude lipid was analyzed with ether extraction in a soxhlet extractor (SER 148, VELP Scientifica, Milano, Italy). Moisture was determined using a dry oven at $105^{\circ} \mathrm{C}$ for $6 \mathrm{~h}$ and also the ash content was determined after combustion at $600^{\circ} \mathrm{C}$ for 4 $\mathrm{h}$ in a muffle furnace. Amino acid composition in the experimental diets and whole body of fish was determined by acid hydrolysis with $6 \mathrm{~N} \mathrm{HCL}$ (reflux for $23 \mathrm{~h}$ at $110^{\circ} \mathrm{C}$ ) 
Table 2. Ingredients and chemical composition of experimental diets

\begin{tabular}{|c|c|c|c|c|c|c|}
\hline \multirow{2}{*}{ Items } & \multicolumn{6}{|c|}{ Diets } \\
\hline & DDG0 & DDG5 & DDG10 & DDG15 & DDG20 & DDG25 \\
\hline \multicolumn{7}{|l|}{ Ingredients (\%) } \\
\hline Pollack fish meal & 60.0 & 60.0 & 60.0 & 60.0 & 60.0 & 60.0 \\
\hline Distillers dried grain powder ${ }^{1}$ & & 5.0 & 10.0 & 15.0 & 20.0 & 25.0 \\
\hline Wheat flour & 23.0 & 18.5 & 14.0 & 9.5 & 5.0 & 1.5 \\
\hline Corn gluten meal & 4.0 & 3.5 & 3.0 & 2.5 & 2.0 & 0.5 \\
\hline$\alpha$-Potato-starch & 5.0 & 5.0 & 5.0 & 5.0 & 5.0 & 5.0 \\
\hline Squid liver oil & 5.0 & 5.0 & 5.0 & 5.0 & 5.0 & 5.0 \\
\hline Vitamin premix ${ }^{2}$ & 1.0 & 1.0 & 1.0 & 1.0 & 1.0 & 1.0 \\
\hline Mineral premix ${ }^{3}$ & 1.0 & 1.0 & 1.0 & 1.0 & 1.0 & 1.0 \\
\hline Vitamin C $(50 \%)^{4}$ & 0.5 & 0.5 & 0.5 & 0.5 & 0.5 & 0.5 \\
\hline Choline salt $(50 \%)$ & 0.3 & 0.3 & 0.3 & 0.3 & 0.3 & 0.3 \\
\hline Taurine & 0.2 & 0.2 & 0.2 & 0.2 & 0.2 & 0.2 \\
\hline \multicolumn{7}{|l|}{ Nutrient content (dry matter basis) } \\
\hline Crude protein $(\%)$ & 48.9 & 48.4 & 48.3 & 48.0 & 47.3 & 47.2 \\
\hline Crude lipid (\%) & 9.6 & 10.1 & 10.4 & 10.6 & 10.9 & 10.8 \\
\hline $\operatorname{Ash}(\%)$ & 13.3 & 13.5 & 13.7 & 13.5 & 13.6 & 14.9 \\
\hline $\mathrm{N}$-free extract ${ }^{5}$ & 28.2 & 28.0 & 27.6 & 27.9 & 28.2 & 27.1 \\
\hline \multicolumn{7}{|c|}{ Essential amino acid composition (\% protein) } \\
\hline Arg & 6.5 & 6.5 & 6.4 & 6.7 & 6.6 & 6.7 \\
\hline His & 2.2 & 2.2 & 2.2 & 2.1 & 2.2 & 2.2 \\
\hline Ile & 3.3 & 3.6 & 3.9 & 2.9 & 3.4 & 3.7 \\
\hline Leu & 8.2 & 8.5 & 8.7 & 8.4 & 8.4 & 8.1 \\
\hline Lys & 7.2 & 7.1 & 6.9 & 6.7 & 6.7 & 6.8 \\
\hline Met+Cys & 3.7 & 3.9 & 4.0 & 3.7 & 4.0 & 4.2 \\
\hline Phe+Tyr & 7.1 & 7.2 & 7.4 & 7.3 & 7.3 & 7.1 \\
\hline Thr & 4.7 & 4.9 & 4.6 & 4.7 & 4.8 & 4.8 \\
\hline Val & 4.0 & 4.3 & 4.5 & 3.6 & 4.2 & 4.5 \\
\hline
\end{tabular}

DDG, distillers dried grain.

${ }^{1}$ Residue obtained by filtration of an aqueous mixture of fermented rice with Aspergillus oryzae and yeasts produced from Incheon Makgeolli factory (Incheon, Korea).

${ }^{2}$ Vitamin premix contained the following amount which were diluted in cellulose ( $\mathrm{g} / \mathrm{kg}$ premix): DL- $\alpha$-tocopheryl acetate, 18.8 ; thiamin hydrochloride, 2.7; riboflavin, 9.1; pyridoxine hydrochloride, 1.8; niacin, 36.4; Ca-D-pantothenate, 12.7; myo-inositol, 181.8; D-biotin, 0.27; folic acid, 0.68; paminobenzoic acid, 18.2; menadione, 1.8; retinyl acetate, 0.73; cholecalciferol, 0.003; cyanocobalamin, 0.003 .

${ }^{3}$ Mineral premix contained the following ingredients (g/kg premix): $\mathrm{MgSO}_{4} \cdot 7 \mathrm{H}_{2} \mathrm{O}, 80.0 ; \mathrm{NaH}_{2} \mathrm{PO}_{4} \cdot 2 \mathrm{H}_{2} \mathrm{O}, 370.0 ; \mathrm{KCl}, 130.0 ; \mathrm{Ferric}$ citrate, 40.0 ; $\mathrm{ZnSO}_{4} \cdot 7 \mathrm{H}_{2} \mathrm{O}, 20.0$; Ca-lactate, 356.5; $\mathrm{CuCl}, 0.2 ; \mathrm{AlCl}_{3} \cdot 6 \mathrm{H}_{2} \mathrm{O}, 0.15 ; \mathrm{KI}, 0.15 ; \mathrm{Na}_{2} \mathrm{Se}_{2} \mathrm{O}_{3}, 0.01 ; \mathrm{MnSO}_{4} \cdot \mathrm{H}_{2} \mathrm{O}, 2.0 ; \mathrm{CoCl}_{2} \cdot 6 \mathrm{H}_{2} \mathrm{O}, 1.0$.

${ }^{4}$ ROVIMIX STAY-C 35. DSM Nutrition Ltd., Seoul, Korea.

${ }^{5}$ Nitrogen-free extract $(\mathrm{NFE})=100-($ crude protein+crude lipid+ash $)$.

followed by using an automatic amino acids analyzer (Hitachi, Tokyo, Japan).

\section{Blood chemistry}

Blood samples were taken from the caudal veins of five fish per tank using 1-mL heparinized syringes. The collected blood was centrifuged $(3,500 \mathrm{~g}$ for $10 \mathrm{~min})$ and the plasma was separated and stored in a $-75^{\circ} \mathrm{C}$ freezer. Plasma total protein, glucose, total cholesterol, glutamicpyruvic transaminase (GPT), phospholipid and triglyceride concentrations were determined using a clinical investigation commercial kit (Asan Pharmaceutical Co., Seoul, Korea).

\section{Radical scavenging activities}

At the end of the feeding trials, five fish per tank were sampled and stored at $-75^{\circ} \mathrm{C}$ for antioxidant activity analysis. Samples were extracted from plasma and liver using extract buffer in $5 \mathrm{mM}$ Tris- $\mathrm{HCl}$ and $35 \mathrm{mM}$ glycine by $\mathrm{pH} 8.4$ with a homogenizer (Wiggenhauser, Berlin, Germany), followed by centrifugation $(13,000 \mathrm{~g}$ for $10 \mathrm{~min}$ at $4^{\circ} \mathrm{C}$ ). The supernatant was then collected and analyzed for its radical scavenging activity.

Assays of 1, 1-Diphenyl-2-picryl-hydrazyl and Alkyl radicals scavenging activity on electron spin resonance spectrometer

$$
\text { 1, 1-Diphenyl-2-picryl-hydrazyl (DPPH) radical }
$$


scavenging activity was evaluated using the method described by Nanjo et al. (1995). A $30 \mu \mathrm{L}$ peptide solution (or ethanol itself as control) was added to $30 \mu \mathrm{L}$ of DPPH $(60 \mu \mathrm{M})$ in ethanol solution. After mixing vigorously for 10 $\mathrm{s}$, the solution was moved into a $100 \mu \mathrm{L}$ quartz capillary tube, and the scavenging activity of peptide on DPPH radical was determined using spectrometer (JEOL Ltd., Tokyo, Japan). After $2 \mathrm{~min}$, the spin adduct was determined using an electron spin resonance (ESR) spectrometer. The measurement conditions were magnetic field, 336.5 $\pm 5 \mathrm{mT}$; power, $5 \mathrm{~mW}$; modulation frequency, $9.41 \mathrm{GHz}$; amplitude; $1 \times 1,000$ and sweep time; $30 \mathrm{~s}$.

Alkyl radicals were determined by 2, 2-azobiz-(2amidinopropane)-hydrochloride (AAPH). The phosphate buffered saline ( $\mathrm{pH}$ 7.4) reaction mixtures included $10 \mathrm{mM}$ AAPH, $10 \mathrm{mM}$ 4-POBN and identified concentrations of samples, which were incubated at $37^{\circ} \mathrm{C}$ in a water bath for 30 min (Hiramoto et al., 1993) and then moved to a capillary tube. The spin adduct was recorded on a spectrometer (JEOL Ltd., Japan). The measurement conditions were as follows: modulation frequency, $100 \mathrm{kHz}$; microwave power, $10 \mathrm{~mW}$; microwave frequency, 9,441 $\mathrm{MHz}$; magnetic field, $336.5 \pm 5 \mathrm{mT}$ and sweep time, $30 \mathrm{~s}$.

The DPPH and alkyl radical scavenging activities (RSA) were computed following equation in which $H$ and $H_{0}$ were the relative peak height of radical signals with and without sample, respectively.

$$
\operatorname{RSA}(\%)=\frac{(1-\mathrm{H})}{\mathrm{H}_{0}} \times 100
$$

\section{Statistical analysis}

The data were subjected to one-way analysis of variance using SPSS version 19.0 (SPSS Inc., Chicago, IL, USA).
Significant differences $(\mathrm{p}<0.05)$ among the means were determined using a Duncan's multiple range test (Duncan, 1955).

\section{RESULTS}

Growth performance, feed utilization and morphological parameters of juvenile red seabream fed the experimental diets containing different levels of DDG are presented in Table 3. No significant differences were identified in survival, weight gain, feed efficiency, daily protein intake, protein efficiency ratio and daily feed intake among the groups ( $p>0.05)$. Also there was no significant difference in morphological parameters, such as condition factor and hepatosomatic index. The results of body composition and essential amino acid composition of juvenile red seabream fed the experimental diets are presented in Table 4. The DDG level did not affect the proximate and amino acid composition of whole body juvenile red seabream ( $p>0.05)$. The results of hematological parameters of plasma in juvenile red seabream are shown in Table 5. Plasma contents of total protein, glucose, total cholesterol, GPT, phospholipid and triglyceride were not affected by dietary DDG levels ( $p>0.05)$. The results of RSA of plasma and liver in juvenile red seabream are presented in Table 6. DPPH and alkyl RSA in the plasma of fish did not show significant differences among treatments. Also, DPPH and alkyl RSA in the liver of fish were not affected by dietary DDG levels ( $p>0.05)$.

\section{DISCUSSION}

The present results show that up to $25 \%$ DDG in the formulated diets did not have a negative effect on the

Table 3. Growth performances, feed utilization and morphological parameters of juvenile red seabream fed the experimental diets for 10 $\mathrm{wks}^{1}$

\begin{tabular}{|c|c|c|c|c|c|c|c|c|}
\hline & \multicolumn{6}{|c|}{ Diets } & \multirow{2}{*}{ SEM } & \multirow{2}{*}{$\mathrm{p}$-value } \\
\hline & DDG0 & DDG5 & DDG10 & DDG15 & DDG20 & DDG25 & & \\
\hline IBW (g) & 10.1 & 10.1 & 10.2 & 10.1 & 10.1 & 10.2 & 0.08 & 0.732 \\
\hline Survival (\%) & 72 & 89 & 72 & 82 & 78 & 78 & 5.09 & 0.135 \\
\hline $\mathrm{WG}(\%)^{2}$ & 269 & 270 & 273 & 279 & 241 & 238 & 16.18 & 0.449 \\
\hline $\mathrm{FE}(\%)^{3}$ & 91 & 92 & 96 & 96 & 87 & 84 & 4.96 & 0.655 \\
\hline $\operatorname{DPI}(\%)^{4}$ & 0.79 & 0.86 & 0.81 & 0.83 & 0.83 & 0.92 & 0.05 & 0.724 \\
\hline $\operatorname{PER}(\%)^{5}$ & 2.01 & 1.90 & 2.15 & 1.99 & 1.85 & 1.76 & 0.13 & 0.538 \\
\hline DFI $(\%)^{6}$ & 1.62 & 1.78 & 1.58 & 1.70 & 1.73 & 1.93 & 0.11 & 0.424 \\
\hline $\mathrm{CF}^{7}$ & 1.71 & 1.77 & 1.70 & 1.73 & 1.74 & 1.82 & 0.06 & 0.735 \\
\hline $\mathrm{HSI}^{8}$ & 2.40 & 2.53 & 2.37 & 2.42 & 2.30 & 2.37 & 0.05 & 0.159 \\
\hline
\end{tabular}

DDG, distillers dried grain; SEM, standard error of mean; IBW, initial body weight; WG, weight gain; FE, feed efficiency; DPI, daily protein intake; PER, protein efficiency ratio; DFI, daily feed intake; $\mathrm{CF}$, condition factor; HSI, hepatosomatic index.

${ }^{1}$ Values are means of triplicate groups. ${ }^{2} \mathrm{WG}=$ (final fish wt. - initial fish wt. $) \times 100 /$ initial fish wt.

${ }^{3} \mathrm{FE}=$ wet weight gain $\times 100 /$ feed intake. ${ }^{4} \mathrm{DPI}=$ protein intake $\times 100 /[($ initial fish wt.+final fish wt. + dead fish wt. $) \times$ days reared/2].

${ }^{5} \mathrm{PER}=$ wet weight gain/protein intake. ${ }^{6} \mathrm{DFI}=$ feed intake $\times 100 /[($ initial fish wt.+final fish wt.+dead fish wt. $) \times \mathrm{days}$ reared/2 $]$.

${ }^{7} \mathrm{CF}=$ fish weight $(\mathrm{g}) \times 100 /$ fish length $(\mathrm{cm})^{3} .{ }^{8} \mathrm{HSI}=$ liver weight $\times 100 /$ body weight. 
Table 4. Proximate and essential amino acid composition of the whole body in juvenile red seabream fed the experimental diets for 10 wks $^{1}$

\begin{tabular}{|c|c|c|c|c|c|c|c|c|}
\hline \multirow{2}{*}{ Items } & \multicolumn{6}{|c|}{ Diets } & \multirow{2}{*}{ SEM } & \multirow{2}{*}{ p-value } \\
\hline & DDG0 & DDG5 & DDG10 & DDG15 & DDG20 & DDG25 & & \\
\hline \multicolumn{9}{|c|}{ Proximate composition (\%) } \\
\hline Moisture & 65.5 & 65.6 & 65.3 & 65.6 & 66.8 & 66.6 & 0.78 & 0.703 \\
\hline Crude protein & 19.0 & 18.6 & 18.9 & 18.4 & 18.3 & 18.4 & 0.34 & 0.612 \\
\hline Crude lipid & 8.3 & 9.1 & 8.6 & 8.7 & 8.3 & 7.5 & 0.53 & 0.478 \\
\hline Ash & 5.7 & 5.2 & 5.7 & 5.6 & 5.6 & 5.7 & 0.24 & 0.635 \\
\hline \multicolumn{9}{|c|}{ Essential amino acids (\% protein) } \\
\hline $\operatorname{Arg}$ & 6.9 & 7.0 & 7.1 & 6.9 & 6.9 & 7.0 & 0.11 & 0.874 \\
\hline His & 2.3 & 2.3 & 2.2 & 2.3 & 2.3 & 2.3 & 0.03 & 0.656 \\
\hline Ile & 3.2 & 3.0 & 2.8 & 3.2 & 3.1 & 2.9 & 0.35 & 0.930 \\
\hline Leu & 7.4 & 7.4 & 7.3 & 7.5 & 7.5 & 7.3 & 0.14 & 0.809 \\
\hline Lys & 8.1 & 8.1 & 7.9 & 8.2 & 8.0 & 8.0 & 0.10 & 0.644 \\
\hline Met+Cys & 3.8 & 3.8 & 3.7 & 3.8 & 3.8 & 3.8 & 0.07 & 0.868 \\
\hline Phe+Tyr & 6.8 & 6.7 & 6.7 & 6.8 & 6.8 & 6.7 & 0.11 & 0.991 \\
\hline Thr & 4.6 & 4.5 & 4.5 & 4.6 & 4.5 & 4.5 & 0.12 & 0.968 \\
\hline Val & 3.6 & 3.4 & 3.2 & 3.7 & 3.6 & 3.3 & 0.33 & 0.909 \\
\hline
\end{tabular}

DDG, distillers dried grain; SEM, standard error of mean.

${ }^{1}$ Values are means of triplicate groups.

growth performance, morphological parameters, body composition and amino acid profile of juvenile red seabream. Results of this research indicate that rice-based DDG can be considered to be a candidate as a feed ingredient for juvenile red seabream. Rice-based DDG might also be a good ingredient in diets for olive flounder (Rahman et al., 2013). Several studies observed a good growth rate of tilapia when fed diets containing corn-based
DDG (Wu et al., 1996,1997; Coyle et al., 2004; Abo-state et al., 2009). This generally agrees with a number of studies showing that $30 \%$ to $40 \%$ corn-based DDG may be included in diets for channel catfish (Tidwell et al., 1990; Webster et al., 1993; Robinson and Li, 2008), rainbow trout (Cheng and Hardy, 2004; Stone et al., 2005; Barnes et al., 2012), hybrid catfish (Zhou et al., 2010) and yellow perch (Schaeffer et al., 2011) without incurring negative effects on

Table 5. Hematological parameters of the plasma in juvenile red seabream fed the experimental diets for $10 \mathrm{wks}^{1}$

\begin{tabular}{lcccccccc}
\hline & \multicolumn{9}{c}{ Diets } & \multirow{2}{*}{ SEM } & \multirow{2}{*}{ p-value } \\
\cline { 2 - 6 } & DDG0 & DDG5 & DDG10 & DDG15 & DDG20 & DDG25 & & \\
\hline Total protein (g/dL) & 4.0 & 3.4 & 3.9 & 3.7 & 3.8 & 3.7 & 0.21 & 0.527 \\
Glucose (mg/dL) & 69 & 53 & 64 & 71 & 52 & 55 & 6.85 & 0.301 \\
Total cholesterol (mg/dL) & 337 & 269 & 351 & 333 & 346 & 367 & 29.24 & 0.498 \\
GPT (IU/L) & 0.7 & 0.7 & 1.0 & 1.3 & 0.7 & 0.3 & 0.30 & 0.334 \\
Phospholipid (mg/dL) & 677 & 694 & 755 & 750 & 792 & 864 & 49.81 & 0.393 \\
Triglyceride (mg/dL) & 162 & 163 & 182 & 193 & 161 & 208 & 18.22 & 0.598 \\
\hline
\end{tabular}

DDG, distillers dried grain; SEM, standard error of mean; GPT, glutamic-pyruvic transaminase.

${ }^{1}$ Values are means of triplicate groups.

Table 6. Radical scavenging activity of the plasma and liver in juvenile red seabream fed the experimental diets for $10 \mathrm{wks}{ }^{1}$

\begin{tabular}{|c|c|c|c|c|c|c|c|c|}
\hline & \multicolumn{6}{|c|}{ Diets } & \multirow{2}{*}{ SEM } & \multirow{2}{*}{ p-value } \\
\hline & DDG0 & DDG5 & DDG10 & DDG15 & DDG20 & DDG25 & & \\
\hline \multicolumn{9}{|l|}{ Plasma } \\
\hline DPPH radical & 63.7 & 77.6 & 77.9 & 83.7 & 80.3 & 84.3 & 4.82 & 0.250 \\
\hline Alkyl radical & 93.2 & 93.9 & 94.0 & 94.5 & 93.6 & 93.4 & 0.46 & 0.092 \\
\hline \multicolumn{9}{|l|}{ Liver } \\
\hline DPPH radical & 74.2 & 77.5 & 79.6 & 81.3 & 81.6 & 81.7 & 1.80 & 0.226 \\
\hline Alkyl radical & 74.1 & 73.0 & 75.6 & 71.6 & 74.3 & 68.6 & 3.55 & 0.454 \\
\hline
\end{tabular}

DDG, distillers dried grain; SEM, standard error of mean; DPPH, 1, 1-Diphenyl-2-picryl-hydrazyl.

${ }^{1}$ Values are means of triplicate groups. 
growth performance. Furthermore, the inclusion of cornbased DDG in the diet may improve palatability of sunshine bass (Thompson et al., 2008). The acceptable growth performance of freshwater fishes fed diet containing DDG is definitely related to various aspects such as improving digestibility (Randall and Drew, 2010) and decreased exposure to anti-nutritional factors (Borgeson et al., 2006). Tidwell et al. (1990) reported that there were no significant differences in fish weight, survival and protein efficiency ratio of channel catfish fed diets containing up to $40 \%$ DDG for 11 weeks. In the present study, survival, weight gain, feed efficiency and protein efficiency ratio of fish fed diets containing up to $25 \%$ DDG were not different among the treatments. We consider the main reason for this result was removing anti-nutritional factors in DDG by means of fermentation. It has been reported that the nutritional profile of palm kernel meal as a constituent in a diet for tilapia Oreochromis sp. could possibly be enhanced by means of fermentation (Ng et al., 2002). Ramachandran et al. (2005) reported that fermentation might considerably reduce the anti-nutritional factors and crude fibre content. Slater et al. (2011) reported that fermentation associated with carbohydrate sources previous to feeding may improve digestibility as well as convenience in juvenile fish diets. During production of DDG from rice, yeasts are widely used to facilitate the fermentation method. The DDG includes a substantial quantity of yeast cells (Zohu et al., 2010) which might be abundant in proteins, B-complex vitamins and $\beta$-glucans. Scientific studies with sea bass (Oliva-Teles and Goncalves, 2001) and sunshine bass (Gause and Trushenski, 2011) reported growth improvement with dietary inclusion of yeast. Li et al. (2011) also ascribed the positive effect of DDG on fish growth to be due to the presence of yeast in DDG. That there was no negative effects due to the high inclusion of DDG in diets for red seabream is probably associated with beneficial effect on DDG during fermentation by Aspergillus oryzae and yeasts with rice.

$\mathrm{Li}$ et al. (2011) reported that different levels of cornbased DDG did not significantly influence the hematological parameters of Nile tilapia, Oreachromis niloticus. Related findings were observed the hematological parameters of juvenile red seabream in the present study. The effect of DDG was not significantly different between treatments in whole body proximate composition of juvenile red seabream. Recently studies with Nile tilapia ( $\mathrm{Li}$ et al., 2011) and rainbow trout (Barnes et al., 2012) revealed that whole body proximate composition was not affected by dietary levels of DDG.

Many studies have shown that there was a direct relationship between antioxidant activity and total phenolic content in vegetables, fruits and grain items (Velioglu et al., 1998; Siriwardhana et al., 2003; Heo et al., 2005). DPPH has been utilized for the determination of free radical scavenging effects on pure antioxidant chemical substances, plant and fruit extracts and food materials (Matsukawa et al., 1997; Park et al., 2005; Wong et al., 2006). However, to date, there is no available information on scavenging activities in fish fed diets containing DDG as an ingredient. Pham and Lee (2007) reported that nutritional dietary supplements of Cheongkukjang (Korean fermented soybean with rice straw) exhibited high DPPH free RSA in parrot fish. Kim et al. (2010) suggested that DPPH radical scavenging activity in juvenile olive flounder was gradually increased by the inclusion of Meju which is fermented soybean meal. Alkyl radicals had been measured applying ESR, generally known as a technique capable of recognizing huge reactive free radicals. Park et al. (2005) reported alkyl radical scavenging effects and noticed the positive impacts using extract from Sargassum thunbergii. In the present study, DPPH and alkyl RSA in plasma and liver of red seabream were not different among all groups. The results indicate that phenolic compounds in DDG in the diets did not influence in radical scavenging activity of juvenile red seabream.

Results of this experiment suggest that DDG has the potential to replace material of plant origin such as wheat flour and corn gluten meal and could be used up to $25 \%$ in diets without incurring negative effects on the growth performance of juvenile red seabream.

\section{ACKNOWLEDGMENTS}

This research was supported by the Fishery Commercialization Technology Development Program (110077-3) and Korea Sea Grant Program funded by Ministry of Oceans and Fisheries in Korea.

\section{REFERENCES}

Abo-state, H. A., A. M. Tahoun, and Y. A. Hammouda. 2009. Effects of replacement of soybean meal by DDGS combined with commercial phytase on Nile tilapia (Oreochromis niloticus) fingerlings growth performance and feed utilization. Am. Eurasian J. Agric. Environ. Sci. 5:473-479.

AOAC (Association of Official Analytical Chemists). 1995. Official Methods of Analysis. 16th edn. Association of Official Analytical Chemists, Arlington, VA, USA.

Barnes, M. E., M. L. Brown, and K. A. Rosentrater. 2012. Initial observations on the inclusion of high protein distillers dried grain into rainbow trout diets. Open Fish Sci. J. 5:21-29.

Borgeson, T. L., V. J. Racz, D. C. Wilkie, L. J. White, and M. D. Drew. 2006. Effect of replacing fishmeal and oil with simple or complex mixtures of vegetable ingredients in diets fed to Nile tilapia (Oreochromis niloticus). Aquac. Nutr. 12:141-149.

Cheng, Z. J. and R. W. Hardy. 2004. Nutritional value of diets containing distiller's dried grain with solubles for rainbow trout, Oncorhynchus mykiss. J. Appl. Aquac. 15:101-113. 
Chevanan, N., K. A. Rosentrater, and K. Muthukumarappan. 2007. Twin-screw extrusion processing of feeds blends containing distillers dried grains with solubles (DDGS). Cereal Chem. 84:428-436.

Chevanan, N., K. A. Rosentrater, and K. Muthukumarappan. 2010. Effects of processing conditions on single screw extrusion of feed ingredients containing DDGS. Food Bioprocess Technol. 3:111-120.

Coyle, S. D., G. J. Mengel, J. H. Tidwell, and C. D. Webster. 2004. Evaluation of growth, feed utilization, and economics of hybrid tilapia, Oreochromis niloticus $\times$ Oreochromis aureus, fed diets containing different protein sources in combination with distillers dried grains with solubles. Aquac. Res. 35:365-370.

Duncan, D. B. 1955. Multiple-range and multiple $F$ tests. Biometrics 11:1-42.

Foscarini, R. 1988. A review: Intensive farming procedure for red sea bream (Pagrus major) in Japan. Aquaculture 72:191-246.

Gause, B. and J. Trushenski. 2011. Replacement of fish meal with ethanol yeast in the diets of sunshine bass. N. Am. J. Aquac. 73:97-103.

He, S., Z. Wu, Y. Liu, N. Wu, Y. Tao, L. Xu, Z. Zhou, B. Yao, and E. Ring $\varnothing$. 2013. Effects of dietary $60 \mathrm{~g} \mathrm{~kg}^{-1}$ dried distiller's grains in least-cost practical diets on production and gut allochthonous bacterial composition of cage-cultured fish: composition among fish species with different natural food habits. Aquac. Nutr. 19:765-772.

Heo, S. J., P. J. Park, E. J. Park, S. K. Kim, and Y. J. Jeon. 2005. Antioxidant activity of enzymatic extracts from a brown seaweed Ecklonia cava by electron spin resonance spectrometry and comet assay. Eur. Food Res. Technol. 221:41-47.

Hertrampf, J. W. and F. Piedad-Pascual. 2000. Handbook on Ingredients for Aquaculture Feeds. Kluwer Academic Publishers, Boston, MA, USA. 573 p.

Hiromoto, K., H. Johkoh, K. I. Sako, and K. Kikugawa. 1993. DNA breaking activity of the carbon-centered radical generated from 2, 2 -azobis- (2-amidinopropane)hydrochloride (AAPH). Free Radic. Res. Comm. 19:323-332.

Jacob, M. E., J. T. Fox, J. S. Drouillard, D. G. Renter, and T. G. Nagaraja. 2008. Effects of dried distiller's grain on fecal prevalence and growth of Escherichia coli $\mathrm{O} 157$ in batch culture fermentations from cattle. Appl. Environ. Microbiol. 74:38-43.

Kannadhason, S., K. Muthukumarappan, and K. A. Rosentrater. 2009. Effects of ingredients and extrusion on aquafeeds containing DDGS and tapioca starch. J. Aquac. Feed Sci. Nutr. 1:6-21.

Kim, S. S., M. A. Pham, K. W. Kim, M. H. Son, and K. J. Lee. 2010. Effects of microbial fermentation of soybean on growth performances, phosphorus availability, and antioxidant activity in diets for juvenile olive flounder (Paralichthys olivaceus). Food Sci. Biotechnol. 19:1605-1610.

Li, M. H., E. H. Robinson, D. F. Oberle, and P. M. Lucas. 2010. Effects of various corn distillers by-products on growth, feed efficiency, and body composition of channel catfish, Ictalurus punctatus. Aquac. Nutr. 16:188-193.

Li, E., C. Lim, C. Cai, and P. H. Klesius. 2011. Growth response and resistance to Streptococcus iniae of Nile tilapia, Oreochromis niloticus, fed diets containing different levels of wheat distillers's dried grains with solubles with or without lysine supplementation. Anim. Feed Sci. Technol. 170:246-255.

Lim, C., M. Yildirim-Aksoy, and P. H. Klesius. 2009. Growth response and resistance to Edwardsiella ictaluri Channel Catfish, Ictalurus punctatus, fed diets containing distiller's dried grains with solubles. J. World Aquac. Soc. 40:182-193.

Matsukawa, R., Z. Dubinsky, E. Kishimoto, K. Masaki, Y. Masuda, T. Takeuchi, M. Chihara, Y. Yamamoto, E. Niki, and I. Karube. 1997. A comparison of screening methods for antioxidant activity in seaweeds. J. Appl. Phycol. 9:29-35.

Nanjo, H., H. Adachi, M. Aketa, T. Mizoguchi, T. Nishihara, and T. Terada. 1995. The role of cysteine in the alteration of bovine liver dihydrodiol dehydrogenase 3 activity. Biochem. J. 310:101-107.

Ng, W. K., H. A. Lim, S. L. Lim, and C. O. Ibrahim. 2002. Nutritive value of palm kernel meal pretreated with enzyme of fermented with Trichoderma koningii (Oudemans) as a dietary ingredient for red hybrid tilapia (Oreochromis sp.). Aquac. Res. 33:1199-1207.

Oliva-Teles, A. and P. Goncalves. 2001. Partial replacement of fishmeal by brewers yeast (Saccaromyces cerevisae) in diets for sea bass (Dicentrarchus labrax) juveniles. Aquaculture 202:269-278.

Park, P. J., S. J. Heo, E. J. Park, S. K. Kim, H. G. Byun, B. T. Jeon, and Y. J. Jeon. 2005. Reactive oxygen scavenging effect of enzymatic extracts from Sargassum thunbergii. J. Agric. Food Chem. 53:6666-6672.

Pham, M. A. and K. J. Lee. 2007. Effects of dietary Cheongkukjang on liver superoxide dismutase activity of parrot fish Oplegnathus fasciatus. J. Aquac. 20:132-139.

Rahman, M. M., J. Choi, and S. M. Lee. 2013. Influences of dietary distillers dried grain level on growth performance, body composition and biochemical parameters of juvenile olive flounder (Paralichthys olivaceus). Aquac. Res. DOI: 10. 1111/are.12157.

Ramachandran, S., A. Bairagi, and A. K. Ray. 2005. Improvement of nutritive value of grass pea (Lathyrus sativus) seed meal in the formulated diets for rohu, Labeo rohita (Hamilton) fingerlings after fermentation with a fish gut bacterium. Bioresour. Technol. 96:1465-1472.

Randall, K. M. and M. D. Drew. 2010. Fractionation of wheat distiller's dried grains and solubles using sieving increases digestible nutrient content in rainbow trout. Anim. Feed Sci. Technol. 159:138-142.

Robinson, E. H. and M. H. Li. 2008. Replacement of soybean meal in channel catfish, Ictalurus punctatus, diets with cottonseed meal and distillers dried grains with solubles. J. World Aquac. Soc. 39:521-527.

Schaeffer, T. W., M. L. Brown, and K. A. Rosentrater. 2009. Performance characteristics of Nile tilapia (Oreochromis niloticus) fed diets containing graded levels of fuel-based distillers dried grains with solubles. J. Aquac. Feed Sci. Nutr. 1:78-83.

Schaeffer, T. W., M. L. Brown, and K. A. Rosentrater. 2011. Effects of dietary distillers dried grains with solubles and soybean meal on extruded pellet characteristics and growth responses of juvenile yellow perch. N. Am. J. Aquac. 73:270278

Shelby, R. A., C. Lim, M. Yildrim-Aksoy, and P. H. Klesius. 2008. 
Effects of distiller's grains with solubles-incorporated diets on growth, immune function and disease resistance in Nile tilapia (Oreochromis niloticus L.). Aquac. Res. 39:1351-1353.

Siriwardhana, N., K. W. Lee, S. H. Kim, J. W. Haw, and Y. J. Jeon. 2003. Antioxidant activity of Hizikia fusiformis on reactive oxygen species scavenging and lipid peroxidation inhibition. Food Sci. Technol. Int. 9:339-346.

Slater, M. J., M. Lassudrie, and A. G. Jeffs. 2011. Method for determining apparent digestibility of carbohydrate and protein sources for artificial diets for juvenile sea cucumber, Australostichopus mollis. J. World Aquac. Soc. 42:714-725.

Stone, D. A. J., R. W. Hardy, F. T. Barrows, and Z. J. Cheng. 2005. Effects of extrusion on nutritional value of diets containing corn gluten meal and corn distiller's dried grain for rainbow trout, Oncorhynchus mykiss. J. Appl. Aquac. 17:1-20.

Thompson, K. R., S. D. Rawles, L. S. Metts, R. G. Smith, A. Wimsatt, A. L. Gannam, R. G. Twibell, R. B. Johnson, Y. J. Brady, and C. D. Webster. 2008. Digestibility of dry matter, protein, lipid, and organic matter of two fish meals, two poultry by-product meals, soybean meal, and distiller's dried grains with solubles in practical diets for sunshine bass, Morone chrysops $\times$ M. saxatilis. J. World Aquac. Soc. 39:352363.

Tidwell, J. H., C. D. Webster, and D. H. Yancey. 1990. Evaluation of distiller's grains with solubles in prepared channel catfish diets. Trans. Ky. Acad. Sci. 51:135-138.
Velioglu, Y. S., G. Mazza, L. Gao, and B. D. Oomah. 1998. Antioxidant activity and total phenolics in selected fruits, vegetables and grain products. J. Agric. Food Chem. 46:41134117.

Webster, C. D., J. H. Tidwell, L. S. Goodgame, and P. B. Johnsen. 1993. Growth, body composition, and organoleptic evaluation of channel catfish fed diets containing different percentages of distiller's grain with solubles. Prog. Fish-Cult. 55:95-100.

Wong, S. P., L. P. Leong, and J. H. W. Koh. 2006. Antioxidant activities of aqueous extracts of selected plants. Food Chem. 99:775-783.

Wu, Y. V., R. R. Rosati, and P. B. Brown. 1996. Effects of diets containing various levels of protein and ethanol co-products from corn on growth of tilapia fry. J. Agric. Food Chem. 44:1491-1493.

Wu, Y. V., R. R. Rosati, and P. B. Brown. 1997. Use of cornderived ethanol co-products and synthetic lysine and tryptophan for growth of tilapia (Oreochromis niloticus) fry. J. Agric. Food Chem. 45:2174-2177.

Zhou, P., W. Zhang, D. A. Davis, and C. Lim. 2010. Growth response and feed utilization of juvenile hybrid catfish fed diets containing distillers's dried grains with solubles to replace a combination of soybean meal and corn meal. N. Am. J. Aquac. 72:298-303. 